\title{
A sokarcú gluténérzékenység: gluténindukált autoimmunitás a bőrgyógyász szemével
}

\author{
Malkovics Tamás dr. ${ }^{1,2}$ - Koszorú Kamilla dr. ${ }^{1,2}$ - Kárpáti Sarolta dr. ${ }^{2}$ \\ Arató András dr. ${ }^{3}$ - Görög Anna dr. ${ }^{2}$ - Sárdy Miklós dr. ${ }^{2}$
}

\begin{abstract}
'Semmelweis Egyetem, Általános Orvostudományi Kar, Doktori Iskola, Klinikai Orvostudományok, Budapest ${ }^{2}$ Semmelweis Egyetem, Általános Orvostudományi Kar, Bőr-, Nemikórtani és Bőronkológiai Klinika, Budapest ${ }^{3}$ Semmelweis Egyetem, Általános Orvostudományi Kar, I. Gyermekgyógyászati Klinika, Budapest
\end{abstract}

A glutén, alimentáris környezeti antigénként, különböző szervrendszereket érintő autoimmun betegségeket tud kiváltani. A kórképek hátterében a gluténtolerancia veleszületett hiánya vagy az élet során bekövetkező elvesztése áll. A gluténindukált autoimmun betegségek között a leggyakoribb a coeliakia, melyet különböző súlyosságú enteropátia jellemez, és melynek a szöveti, 2-es típusú transzglutamináz az autoantigénje. A coeliakia extraintestinalis tünetei között azonban néha olyan bőr- és idegrendszeri kórképek jellegzetességei is megtalálhatók, melyek hátterében további transzglutamináz-autoimmunitás kialakulása áll. Idesorolható a hevesen viszkető, polimorf autoimmun bőrbetegség, a dermatitis herpetiformis (transzglutamináz-3-autoimmunitás) és a centrális és/vagy perifériás neurológiai károsodások egy jellegzetes csoportja (transzglutamináz-6-autoimmunitás). Az indukált autoimmunitás reverzibilis, a szigorúan tartott gluténmentes diéta mellett a coeliakia és a bőrtünetek elmúlnak, de az idegrendszeri tünetek egy része maradandó. Az elmúlt évtizedben beszámoltak gluténérzékeny, transzglutamináz-6-pozitív, nem coeliakiás (transzglutamináz-2-negatív) betegekről is. A gluténszenzitivitás sokféle megjelenését ma is erősen kutatják. Fontos a korai felismerés és a kórképek interdiszciplináris szemléletû kezelése. A coeliakia családi szúrővizsgálatokkal való korai felismerése és a tünetmentes egyének diétás kezelése is nagy jelentôségû a gluténérzékenység által kiváltott hiányállapotok és a társuló egyéb betegségek kialakulásának megelőzésében.

Orv Hetil. 2021; 162(28): 1107-1118.

Kulcsszavak: dermatitis herpetiformis, coeliakia, gluténérzékenység, gluténneuropátia, gluténmentes diéta

\section{The many-faced gluten sensitivity: Gluten-induced autoimmunity from dermatological point of view}

Autoimmune diseases induced by digestion of gluten, an environmental antigen, can affect different organ systems. The diseases develop in individuals with congenital or acquired loss of gluten tolerance for life. Amongst the gluteninduced autoimmune diseases, celiac disease is the most common one, characterized by an enteropathy of varying severity. Here the target autoantigen is tissue (type 2) transglutaminase. While the extraintestinal manifestations of celiac disease are complex, they may include characteristics of certain skin and nervous system disorders that develop due to additional transglutaminase autoimmunities. Such diseases are the severely pruritic, polymorphic autoimmune skin disease, dermatitis herpetiformis due to epidermal (type 3) transglutaminase autoimmunity, and a distinctive group of gluten-sensitive neuropathies with central and/or peripheral neurological involvement caused by type 6 transglutaminase autoimmunity. While the celiac and skin autoimmune diseases gradually get into remission under a strict gluten-free diet, some neurological symptoms may persist. In the last decade, gluten-induced transglutaminase 6 positive but non-celiac (transglutaminase 2 negative) patients were reported. Today, various manifestations of gluten sensitivity are under extensive research. Early detection and interdisciplinary treatment of these disorders are important. Family screenings are of particular relevance in early recognition and dietary treatment of latent disease forms in order to prevent enteropathy-induced, malabsorption-related and other associated co-morbidities.

Keywords: dermatitis herpetiformis, coeliac disease, gluten sensitivity, gluten neuropathy, gluten-free diet

Malkovics T, Koszorú K, Kárpáti S, Arató A, Görög A, Sárdy M. [The many-faced gluten sensitivity: Gluten-induced autoimmunity from dermatological point of view]. Orv Hetil. 2021; 162(28): 1107-1118.

(Beérkezett: 2020. augusztus 28.; elfogadva: 2021. január 29.) 


\section{Rövidítések}

AGA = antigliadin-antitest; anti-DGP = deamidált gliadin-peptid elleni antitest; $\mathrm{CD}=$ (cluster of differentiation) differenciációs klaszter; DIF = direkt immunfluoreszcencia; DGP = deamidált gliadin-peptid; ELISA = (enzyme-linked immunosorbent assay) enzimhez kötött immunszorbensteszt; EMA = endomysiumellenes antitest; ESPGHAN $=($ European Society for Paediatric Gastroenterology, Hepatology and Nutrition) Európai Gyermekgasztroenterológiai, Hepatológiai és Táplálkozástudományi Társaság; GMD = gluténmentes diéta; GWAS = (genome-wide association study) a genom egészére kiterjedő asszociációs vizsgálat; HLA = humán leukocytaantigén; IgA = immunglobulin-A; IgE = immunglobulin-E; IL = interleukin; NCGS = nem coeliakiás gluténérzékenység; TG = transzglutamináz; UV = (ultraviolet) ultraibolya

A glutén mindennapi táplálékunk része, amely általában semmilyen problémát nem okoz. Egyesekben azonban veleszületetten hiányozhat, másokban az élet során átmenetileg vagy véglegesen megszúnhet a gluténtolerancia. A glutént mindenkinek a szervezete idegenként ismeri fel, és fogyasztására különböző immunológiai reakciókkal válaszol. Ez azonban fiziológiás körülmények között nem okoz betegséget, mint ahogy a mikrobiom tagjaival szembeni immunválasz sem. Míg a gluténtolerancia hiányának, illetve annak elvesztésének oka ma még nem teljesen tisztázott, egyre többet tudunk a gluténindukált allergiás és autoimmun betegségek patomechanizmusáról. Ebben a cikkben a glutén mint környezeti antigén által indukált, nagyrészt reverzibilis, gluténmentes diétával (GMD) korrigálható autoimmun betegségeket tekintjük át, elsősorban a bőrtünetek szempontjából. További publikációban tervezzük a lisztallergiák tárgyalását.

\section{A coeliakia epidemiológiája és a gluténbevitel}

A legrégebben dokumentált lisztérzékenység béltünetek formájában jelentkezett. Irodalmi utalások szerint már az ókorban is létezett lisztszenzitív enteropátia, feltehetően coeliakia is. A kórképet a múlt század közepéig elsősorban a gyermekkor ritka betegségének tartották, ma már tudjuk, hogy viszonylag gyakori, és bármely életkorban kialakulhat.

A coeliakia a kaukázusi populáció legalább 1-2\%-át érinti, míg például Távol-Keleten alig fordul elő. Több autoimmun betegséghez hasonlóan incidenciája emelkedő tendenciát mutat, többek közt az 1990-es évek végén megjelenó specifikusabb szerodiagnosztikai teszteknek köszönhetóen [1]. A magyar véradók 0,6\%-a bizonyult anti-szövetitranszglutamináz (TG2)-IgA-pozitívnak egy hazai felmérés során [2].

A betegség kialakulására a korai (4 hónapos kor előtti) intenzív gluténterhelés mellett feltehetően a túl későn
(12 hónapos kor után) megkezdett hozzátáplálás is hajlamosít.

A kezeletlen coeliakiás betegek mortalitási rátája emelkedett az átlagpopulációhoz képest, amit a társuló egyéb megbetegedések megnövekedett előfordulása okoz. GMD mellett a mortalitási ráta néhány év alatt visszaállhat az átlagpopuláció szintjére. Valószínú, hogy coeliakiás betegekben az élet során elfogyasztott glutén összmennyisége befolyásolja egyes malignus folyamatok megjelenésének gyakoriságát.

\section{Háttérismeretek: a gluténérzékenységhez társult bélbetegségek spektruma}

A gluténtartalmú ételek fogyasztása az arra fogékony személyekben többféle etiológiával képes megbetegedést kiváltani. A vékonybélben észlelhető eltérések szerint, a patogenezis alapján 3 fŏ csoportot különböztetünk meg.

Az első csoportba a legrégebb óta ismert, autoimmun coeliakia tartozik, melynek lappangó formáiban az idő elörehaladtával kifejlődhetnek extraintestinalis autoimmun megnyilvánulási formák is, például bőr- [3] vagy neurológiai [4] tünetekkel.

A második csoportba tartoznak a gabonaallergiával járó megbetegedések, melyek lehetnek IgE- és nem IgEmediáltak. Az allergiás reakciók irányulhatnak a gabonában található egy vagy több komponens, köztük a glutén ellen is.

A harmadik csoportban különböző nómenklatúrákkal találkozunk. Az ún. nem coeliakiás gluténérzékenység (NCGS) a GMD mellett javuló, dominálóan gastrointestinalis, de szisztémás és neuropszichiátriai tüneteket is okozó, TG2-negatív, szövettanilag nehezen definiálható enteropátia. Emellett néha használják az ún. nem coeliakiás lisztérzékenység diagnózist is, mely azt is jelzi, hogy nemcsak a glutén, de a lisztben levő egyéb összetevő́k, például a nikkel, a fermentábilis oligo-, di-, monoszacharidok és poliolok (például a fruktánok), valamint az amiláz- és a tripszininhibitorok is kiválthatják a kórkép tüneteit. A kérdés megnyugtató tisztázása még várat magára. A harmadik csoportba tartozó betegek mintegy felében pozitív a normálimmunválaszt jelző (IgG/IgA) antigliadin-antitestet (AGA) és sokszor a deamidált gliadin-peptidet (DGP) mérő teszt is, ugyanakkor a coeliakiára specifikus TG2-autoellenanyagok nem mutathatók ki. Míg az NCGS-t klinikai sajátságai miatt egyes források az irritábilisbél-szindróma egyik alcsoportjának tartják, újabb adatok szerint az NCGS-ben (coeliakiában is) mérhető kóros szérumzonulinszint nagy biztonsággal képes elkülöníteni ezen pácienseket a hasonló béltüneteket mutató irritábilisbél-szindrómás betegektől. A GMD hatása a csoportban a zonulinpozitív NCGS-betegek között a legeredményesebb. A jövőben ez a teszt mint biomarker jöhet szóba az NCGSpáciensek diagnózisában [5]. 


\section{A coeliakia és a dermatitis herpetiformis közös genetikai háttere}

Diagnosztikus értékű genetikai adatok igazolják, hogy a coeliakia, az ahhoz társuló gluténszenzitív neuropátia és a dermatitis herpetiformis kialakulásában az öröklődő hajlamnak is szerepe van $[4,6]$.

Mind a coeliakia (1-2\%), mind a dermatitis herpetiformis $(75,3 / 100000$ fó) legmagasabb előfordulását a kaukázusi populációban mérték. Ezen két betegségben megegyező a kapcsolat egyes HLA-DQ2 vagy HLA-DQ8 allélok mint hajlamosító tényezők jelenléte között. A betegek 90\%-a hordozza a HLA-DQ2.5 (DQAl*05, DQB1 *02) allélokat és 5-5\%-a HLA-DQ2.2 (DQAl *02:01， DQBl *02:02) vagy a HLA-DQ8 (DQAl*03, DQB1*03:02) allélokat [7].

Teljesgenom-asszociációs vizsgálattal (genome-wide association study, GWAS) pedig további 39, nem HLAasszociált locust is azonosítottak, melyek érdekessége, hogy többségük legalább egy másik autoimmun betegségre is hajlamosít.

Az említett HLA-DQ2 és HLA-DQ8 allélokat a magyar lakosság 20-25\%-a hordozza [8]. A coeliakiás betegek elsőfokú rokonainak 10-15\%-ánál alakul ki coeliakia vagy dermatitis herpetiformis. Mindezek alapján a gluténszenzitív autoimmunitásokat poligénes öröklődésű és multifaktoriális (környezeti és immunológiai) tényezők által meghatározott betegségeknek tartjuk [9].

A genetikai hajlam meghatározó szerepét támasztják alá az ikervizsgálatok is. Monozigóta ikerpárokra jellemző a konkordáns coeliakia vagy egyiküknél dermatitis herpetiformis kialakulása. A coeliakia súlyossága és a tünetek kialakulása azonban eltérő, ami az epigenetikai különbségekre és a környezeti faktorok fontosságára hívja fel a figyelmet [10].

A coeliakiához társuló neurológiai betegek esetében is jellemző a HLA-DQ2 és HLA-DQ8 allélvariánsok előfordulása, egy szignifikáns részük azonban sem HLADQ2, sem HLA-DQ8 alléllal nem rendelkezik. A jövőben ezen betegek vizsgálata segíthet mélyebben megérteni a betegség egyedi tulajdonságait.

\section{A coeliakia patogenezise}

A coeliakia a prediszponáló genetikai hajlamú egyénekben feltehetően környezeti hatásokat követően keletkezik (például infektív enteritis). A bél immunrendszere idegenként ismeri fel a glutént, és T-sejtes, majd B-sejtes, plazmasejtes (humoralis) immunválaszt indukál a glutén és komponensei ellen. A termelt antiglutén-ellenanyagok nem specifikusak coeliakiára, és jelenlétük nem jelent intoleranciát. Elhúzódó enteralis kórállapot mellett viszont a vékonybél lamina propriájába jelentős mennyiségben kerülhetnek az emésztőenzimek által még nem vagy csak részben megemésztett glutén-peptidek. Bizo- nyos körülmények között a lamina propriában lévő TG2 képes deamidálni ezen peptideket, amelyek ezáltal sokkal immunogénebbé válnak a megfelelő HLA antigénekkel rendelkező egyénekben. Továbbá a TG2 képes önmagát kovalensen a glutén-peptidekhez kötni, s ezáltal gluténvezérelt anti-TG2 autoimmun választ indítani, azaz gluténspecifikus T-sejtekkel indukálni TG2-specifikus B-sejtek autoantitest-termelését.

Kialakul a coeliakiára jellemző gluténdependens, diéta mellett reverzibilis gastrointestinalis kórkép, melyet jejunalis villusatrophia, cryptahyperplasia és az intraepithelialis lymphocyták számának emelkedése jellemez a Marshklasszifikáció szerint [11].

Egy in vitro kísérlet eredménye arra utal, hogy az elfogyasztott glutén a vékonybél-nyálkahártya apicalis felszínén a CXCR3-receptorokhoz kötődhet, ami zonulinfelszabadulást előidézve átmeneti hámpermeabilitást okozhat, a hámsejtek közötti 'tight junction' kapcsolatok fellazulásával. Ez a fiziológiás folyamat más barriereken is megfigyelhető, de csak az arra fogékony egyénekben jut kóroki szerephez ('bakers' asthma' [pékek asztmája]). A jelenség coeliakiában betöltött szerepének bizonyítása in vivo még várat magára. A lamina propria felé történő transzcelluláris gluténtranszportban a CD71-transzferrinreceptor is részt vesz.

Sok más betegséghez hasonlóan a bélmikrobiom oki szerepe coeliakiában is felmerül, mivel összetétele megváltozik a betegség során. Környezeti hatások miatt felborul a bél baktériumflórája és immunrendszere közti egyensúly, ami befolyásolja a mikrobiom összetételét és a bél barrierfunkcióját is. Így a vékonybélben a proinflammatoricus folyamatok kerülnek túlsúlyba.

A dermatitis herpetiformis eseteiben a duodenojejunalis bélszakaszban az enyhe, kis kiterjedésű vagy szigetszerüen jelentkező morfológiai károsodás a gyakori [12]. Ezekben az esetekben diagnosztikus jelentőségű lehet a direkt immunfluoreszcenciás (DIF-) eljárással kimutatható, jellegzetes anti-TG2-IgA-festődés a lamina propriában [13-15].

\section{A transzglutaminázok}

A TG-enzimcsalád 9 tagja ismert, többségük poszttranszlációs módosítással megváltoztatja a fehérjék struktúráját és aktivitását. Nagyfokú homológiát mutatnak, több közös epitóppal rendelkeznek. A gluténérzékenység során autoantigénné válhat a TG2, a TG3 és a TG6 [7].

A dermatitis herpetiformis jellegzetes autoantigénje a TG3. Ez ellen termelődnek a szelektív és nagy aviditású autoantitestek, melyek TG3-IgA-komplexet képeznek a keringésben és a börben [16, 17].

A TG6 elleni autoellenanyagok fontos szerepet játszanak a gluténindukált idegrendszeri eltérések kialakulásában [4]. 


\section{A coeliakia klinikuma a bőrgyógyász szemével}

A coeliakia klinikai megjelenése rendkívül változatos. A klasszikus, enteralis tünetekkel járó forma mellett gyakoribb a kórkép tünetszegény, ún. néma vagy 'silent' (bélpatológia igazolható, szeropozitív) és tünetmentes latens (bélpatológia nem igazolható, lehet szeropozitív) lefolyása. A súlyos formák típusosan kisdedkorban jelentkeznek, de bármely életkorban kialakulhatnak. A betegséget hordozó egyénekre sokszor csak a szürővizsgálattal kimutatható keringő ellenanyag hívja fel a figyelmet, míg a klinikai tünetek és a bélbolyhok szövettana kevéssé jellegzetes.

A coeliakia elégtelen diétával kezelt formáiban a fizikai és/vagy a pszichés status gyengülése mellett romlik az életminőség, és az átlagpopulációénál korábbi a halálozás [18], míg szigorú GMD mellett mindezekben jelentős javulás érhető el [19].

1. táblázat $\mid \begin{aligned} & \text { Felszívódási zavarhoz társuló bőrgyógyászati tünetek, hiányálla- } \\ & \text { potok }\end{aligned}$

\begin{tabular}{ll}
\hline A-vitamin-hiány & $\begin{array}{l}\text { Száraz bőr, follicularis hyperkeratosis, } \\
\text { körömeltérések }\end{array}$ \\
\hline Cinkhiány & $\begin{array}{l}\text { Fóként perioralis és acralis dermatitis, } \\
\text { diffúz alopecia, fogzománcdefektus }\end{array}$ \\
\hline $\begin{array}{l}\text { Vashiány, B } \text { 12-vitamin- }_{\text {hiány }} \\
\text { Körömdystrophia, koilonychia, diffúz } \\
\text { hajhullás, anaemia, glossitis, cheilitis } \\
\text { angularis, stomatitis }\end{array}$ \\
$\begin{array}{l}\text { D }_{3} \text {-vitamin-, kalcium- és } \\
\text { foszfáthiány, parathor- } \\
\text { mon-emelkedés }\end{array}$ & Korai osteoporosis \\
\hline
\end{tabular}

2. táblázat Gluténszenzitív enteropátia és a dermatitis herpetiformishoz gyakrabban társuló egyéb immunológiai betegségek

\begin{tabular}{|c|c|}
\hline 1. & 1-es típusú diabetes mellitus \\
\hline 2. & Hashimoto-thyreoiditis \\
\hline 3. & Vitiligo \\
\hline 4. & Alopecia areata \\
\hline 5. & Anaemia perniciosa \\
\hline 6. & Parciális IgA-deficientia \\
\hline 7. & Lupus erythematosus \\
\hline 8. & Sjögren-szindróma \\
\hline 9. & Rheumatoid arthritis \\
\hline 10. & IgA-nephropathia \\
\hline 11. & Bullosus pemphigoid \\
\hline 12. & Primer biliaris cirrhosis \\
\hline 13. & Achlorhydriás atrophiás gastritis \\
\hline 14. & Atopiás dermatitis \\
\hline 15. & Psoriasis \\
\hline 16. & Sclerosis multiplex \\
\hline
\end{tabular}

A kialakult felszívódási zavarhoz hiányállapotok és bőrgyógyászati tünetek is társulhatnak. Ilyen lehet az A-vitamin-hiány, a száraz bőr, a cinkhiány, a diffúz hajhullás, a vashiány (körömdystrophia, koilonychia), $\mathrm{B}_{12^{-}}$ hiány, jellegzetes fogzománceltérések, korai osteoporosis (1. táblázat) $[6,20,21]$.

Elsősorban az ilyen betegekben és az elégtelenül diétázók között várható, hogy a tartósan fennálló, TG2 ellen irányuló autoimmun reakció mellett kialakul egy másodlagos (TG3-, illetve TG6-) autoimmunitás is, jellegzetesen a dermatitis herpetiformis és a neuropátia [4]. Mindezen kórformák gyakran társulnak egyéb immunbetegségekkel is. Előfordulhat alopecia areata, 1-es típusú diabetes mellitus, autoimmun hyper- vagy hypothyreosis okozta bőrtünetek, szisztémás lupus erythematosus, a Sjögren-szindróma bőrtünetei, de például az atopiás dermatitis is gyakoribb (2. táblázat) [6, 20].

\section{A gluténszenzitív kórképek diagnosztikája}

\section{Szerológia}

Az elsőként választandó módszer az anti-TG2-IgA-antitestek vizsgálata ELISA-eljárással. Kétes esetben az eredményt ajánlott indirekt immunfluoreszcenciás vizsgálattal (endomysiumellenes antitest, EMA) verifikálni. Coeliakiában és dermatitis herpetiformisban az átlagosnál gyakrabban fordul elő IgA-deficientia, ezért minden szeronegatív esetben indokolt a szérum-IgA-szint, deficientia esetén az anti-DGP (deamidált gliadin-peptid elleni antitest) és a TG2-IgG-titer meghatározása is [11].

\section{Az endoszkópia és a bélbiopszia kérdése}

A biopszia endoszkópos vizsgálat során történik, mely a kezeletlen coeliákiás esetek kétharmadában bélboholyatrophiát jelző, jellegzetes makroszkópos képet mutat. A dermatitis herpetiformis betegek harmadában tünhet normálisnak a mucosa. Az elvégzett hisztopatológiai kép a Marsh-klasszifikáció szerint kerül értékelésre [11].

A European Society for Paediatric Gastroenterology, Hepatology and Nutrition (ESPGHAN) legfrissebb, 2020. évi ajánlása szerint gyermekkorban eltekinthetünk a bélbiopsziától bizonyos feltételek teljesülése esetén: az anti-TG2-IgA-titer nagyobb vagy egyenlő a legmagasabb normáltiter tízszeresénél, és az EMA-vizsgálat is megerősíti a diagnózist. IgA-hiányos páciensek esetében nem ajánlott a vizsgálat elmulasztása [22]. Bőrbiopsziával igazolt dermatitis herpetiformis fennállása esetén a keringő TG2-IgA-ellenanyag elleni pozitivitás megléte elegendő lehet, amennyiben egyéb panaszok (atrophiás gastritis, hasi panaszok) fennállása a beavatkozást nem indokolja. A jelenleg érvényes európai dermatitis herpetiformis szakmai előirat szerint a gasztroenterológus szakorvos kompetenciája eldönteni, hogy szükséges-e bélbiopszia egy adott dermatitis herpetiformisos betegnél. 


\section{HLA-tipizálás a diagnosztikában}

A coeliakia és a dermatitis herpetiformis diagnózisakor a mindkét betegségre jellemző HLA-DQ2 vagy HLADQ8 haplotípusallélok tesztelése csak kivételes esetekben (fóleg a diagnózis kizárására) javasolt. Az allélok megléte közel 100\%-os mindkét betegségben, negatív prediktív értékük magas. A vizsgálat elvégzése indokolt lehet például a már GMD-n levő betegek esetén $[4,6$, 22 ]. Tekintettel azonban az igen alacsony pozitív prediktív értékre, a diagnózis felállításához nem elég specifikus, így ezen okból az elvégzése nem indikált [22].

\section{A gluténszenzitív kórképek közös kezelése}

Az idesorolható különböző kórképeknek a mai tudásunk szerint ismert közös gyógymódja az élethosszig tartó, szigorú GMD. A diéta hatására mérséklődnek a klinikai tünetek, csökken a glutén, a gliadin, a DGP elleni ellenanyagok titere. Csökkennek, majd idővel el is tünnek a másodlagosan indukált autoantitestek is a keringésból. Coeliakiában például az anti-TG2-IgA a GMD mellett mintegy 6-12 hónap alatt negatív lesz [4]. A különbözó ellenanyagok időnkénti kontrolljával információt kaphatunk a GMD-hoz való viszonyulásról is. GMD hatására a reverzibilisen károsodott bélnyálkahártya teljes remisszióba kerül.

\section{A coeliakia extraintestinalis manifesztációi bőrgyógyászati szempontból}

Hosszú ideig lappangó, kezeletlen coeliakia talaján kifejlődhetnek a gluténérzékenység más szervrendszereket érintő formái is.

\section{Dermatitis herpetiformis}

A dermatitis herpetiformis krónikus, viszkető, polimorf bőrtünetei a rendszerint lappangó formában zajló coeliakiához társulnak. A glutén által indukált bőrbetegség az autoimmun bullosus dermatosisokhoz sorolható. GMD mellett a bőrelváltozás fokozatosan megszúnik. Diéta nélkül spontán remisszió csak ritkán fordul elő, és a társuló, lappangó coeliakia megmarad.

\section{Klinikai tünetek}

A betegségre jellemző a krónikus, intermittáló lefolyás. A bőrtüneteket a leggyakrabban a könyökön, a térden és a sacroglutealis régióban találjuk, ahol nagyobb mechanikai igénybevételnek (feszülés, nyomás) van kitéve a bőr (1. ábra [21] és 2/a ábra). A nyári hónapokban az UVsugárzás hatására a tünetek enyhülhetnek, a bőr átmenetileg akár tünetmentessé válhat. A GMD bevezetését követően a bőrtünetek mérséklődnek, de általában csak lassan, hónapok, esetleg 1-2 év alatt múlnak el [6, 23].

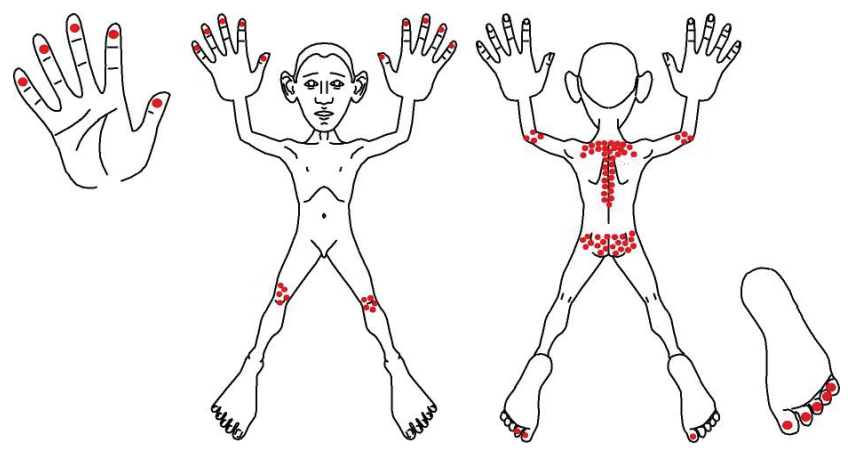

1. ábra

A dermatitis herpetiformis klinikai diagnózisát a tünetek szimmetrikus, regionális megoszlása sugallja a predilekciós helyeken. Típusosan a nyomásnak, feszülésnek kitett területek érintettek. Acralis purpurák is megjelenhetnek az ujjakon. Az ábra használatát a Medicina Könyvkiadó engedélyezte [21]
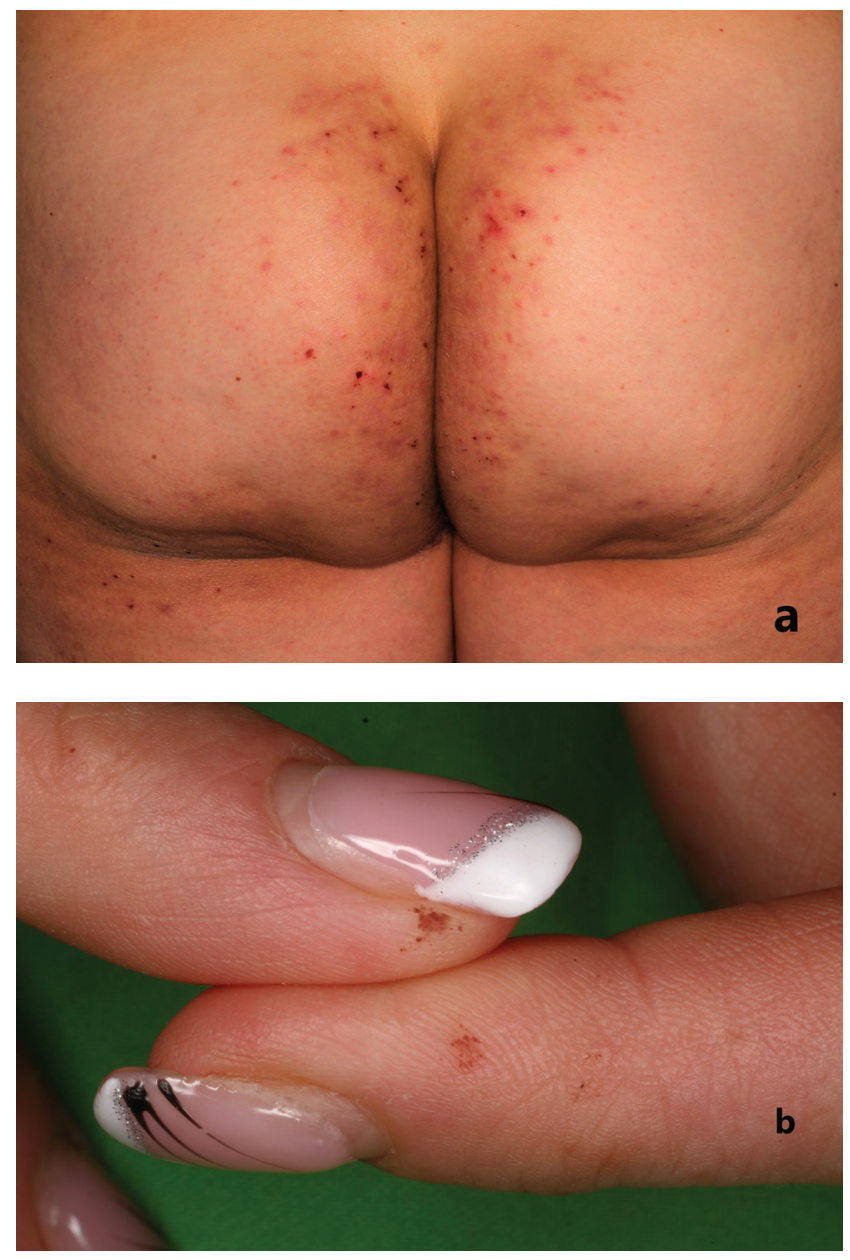

2. ábra $\mid$ Típusos börtünetek dermatitis herpetiformisban: a) polimorf tünetek: erythemás papulák, excoriatiós, erodált vesiculák, pörkkel fedett apró erosiók a glutealis régióban; b) purpurák az ujjakon

A diagnózisra utal a viszkető bőrtünetek szimmetrikus, csoportos elrendeződése, lokalizációja és polimorf jellege (1. ábra [21] és 2/a ábra). Az erythemás, urticariform papulák, herpetiform vesiculák és seropapulák, valamint pörkkel fedett kis erosiók és excoriatiók mellett ritkábban látunk feszes bullákat. A residualis hipo- és hi- 
perpigmentáció tovább színesíti a klinikai képet [24, 25]. A kéz, kevésbé a láb ujjain megjelenő purpurák nem gyakoriak, de a dermatitis herpetiformisra jellegzetesek, és néha az egyedüli bőrtünetei lehetnek (2/b ábra). Makroszkóposan sokszor nem láthatók, dermatoszkóppal azonban igen, ezért klinikai gyanú esetén a betegek ujjait dermatoszkóppal is meg kell vizsgálni. Ezen acralis purpurák is a TG3-IgA keringő immunkomplexek jelenlétére utalnak $[7,26]$. A dermatitis herpetiformisra jellemző bőrtünetek mellett a felszívódási zavarok, hiánybetegségek és a kórképhez társuló, nem gluténdependens immunbetegségek börtünetei is kialakulhatnak (2. táblázat) $[6,20]$. A nedvedző bőrtünetek, a heves viszketés, a lappangó felszívódási zavarok (1. táblázat) [21] mellett ma már figyelünk a neurológiai, például paresztéziás bőrpanaszokat okozó perifériás neuropátiák kialakulására is (ld. később). A késleltetett hatású GMD terhe mellett mindez számottevően rontja az életminőséget, így a páciensek mintegy 20\%-ánál jelentkezik valamilyen neuropszichiátriai eltérés is [19, 27].

\section{Epidemiológia}

Míg a coeliakia incidenciája - többek között az 1990-es években megjelenő újfajta szerodiagnosztikus teszteknek köszönhetően - növekvő tendenciát mutat, addig a dermatitis herpetiformis incidenciája csökken. Ez valószínúleg a coeliakia egyre korábbi felismerésére és a lappangó coeliakiás esetek kiszürésére vezethető vissza. A szigorú GMD gyors megkezdése nagy valószínűséggel megakadályozza a bőrtünetek kifejlődését [1, 18, 28].

A legtöbb információ és így a citált epidemiológiai adatok Finnországból származnak, ahol gyakori a dermatitis herpetiformis előfordulása. A betegség kezdete átlagosan 42,8 év, de bármely életkorban kialakulhat. A prevalencia 75,3/100 000 fó, ez a coeliakia előfordulásának nyolcada. A férfiak és a nók aránya 1,1 : l volt. A vizsgált, háromszor 10 éves időszakban a bőrtünetek megjelenésekor az átlagéletkor férfiak esetén 35,3-ról 51,1-re emelkedett, míg nóknél 36,3-ról 45,8-ra. Az incidencia 1980 és 2009 között 5,2/100 000 forról 2,7/100 000 före csökkent. A vizsgált 476, dermatitis herpetiformisos páciens 3,8\%-ánál gyermekkorban diagnosztizálták a betegséget [29]. Finnországban a diétázó dermatitis herpetiformis betegek összhalálozása és cardiovascularis halálozása is csökkent az átlagpopulációéhoz képest. Ez valószínúleg a szigorúan betartott GMD-nak (a páciensek 71,5\%-a), a rendszeres orvosi kontrollnak, továbbá közöttük a dohányzás és a hypercholesterinaemia kedvezőbb arányának köszönhető [30].

\section{Patogenezis}

Dermatitis herpetiformisban kórjelző a granuláris eloszlást mutató IgA-depozitumok kimutatása a bőr papillaris dermisében [18]. Ez a patológiás cutan IgA a TG3-mal komplexben van jelen, ami az epidermisból vagy a kerin- gésből a papillaris dermisbe jutó TG3-IgA-immunkomplexek jelenlétével magyarázható [16, 23, 26]. A többi autoimmun, hólyagos bőrbetegséggel ellentétben dermatitis herpetiformisban nincsenek a bőr strukturális elemeihez, például a dermalis extracelluláris mátrixhoz kötődő keringő IgA-antitestek. Keringő és a célszervben is identikus kötődést mutatnak azonban az anti-TG2IgA-ellenanyagok, melyek a coeliakiához hasonlóan a jejunumhoz kötődnek $[13,15,31]$. A pathognomicus TG3-IgA-csapadék dermatitis herpetiformisban a tünetmentes bőrterületeken is éveken át kimutatható. A mechanikus hatásnak kitett bőrterületeken feltehetően TG3 szabadul fel az epidermalis keratinocytákból mechanikus hatásra, és ez diffundál a dermisbe, illetve a keratinocytákból származnak a proinflammatoricus citokinek. A jellegzetes acralis bőrtünetek kialakulásához pedig feltételezhetően egyéb faktorok - mint például a mikrocirkulációt károsító cryofibrinogenaemia - is szükségesek [32].

A dermisben lévő TG3-IgA-immunkomplexben a TG3 megőrzi enzimatikus aktivitását. Bőrminták immunhisztokémiai vizsgálata során kiderült, hogy nemcsak az immunkomplex- és fibrinogéndepozitumok elhelyezkedése egyezik meg, hanem az általuk adott jel intenzitása is. Az enzimatikusan aktív TG3 valószínúleg fibrinogént köt, ami hozzájárulhat az aktív bőrtünetek kialakulásához [33]. Kezeletlen dermatitis herpetiformisban a plazma fibrinolitikus potenciálja meggyengül, és az alvadási folyamat során a képződő alvadék struktúráját kóros, vaskos fibrinszálak alkotják. Dapszon alkalmazása in vivo és in vitro is korrigálni tudja a fibrinolízis ezen eltérését [34]. Jellemzően nagy arányban társul cryofibrinogenaemia dermatitis herpetiformishoz [32].

Keringő anti-TG3-IgA-ellenanyagok coeliakiában is kimutathatók. Összefüggés van a coeliakia diagnózisakor mért életkor és a szérum anti-TG3-antitestje elleni pozitivitás emelkedése között. A hosszan tartó, kezeletlen coeliakia eseteiben várható a szekunder TG3-autoimmunitás kialakulása [3]. Az IgA-típusú TG3-ellenanyag termelődése a TG2-autoellenanyagokhoz hasonlóan valószínúleg a bélben zajlik [35]. A dermatitis herpetiformisos páciensek szérumában nagy aviditású és affinitású keringő anti-TG3-antitestek mutathatók ki. Coeliakiás páciensekben az anti-TG3-antitest elleni pozitivitás gyengébb, és feltehetően a TG2-TG3-keresztreakció eredménye. Ezt igazolja, hogy a TG3-antitestek rekombináns TG2-vel abszorbeálhatók, míg dermatitis herpetiformisos páciensektől vett szérum esetén a preabszorbció után visszamarad egy nagy aviditású anti-TG3-antitest-szubpopuláció. A poliklonális IgA-antitestek ugyanis dinamikusan ismernek fel különböző epitópokat („epitope spreading”), ami a TG3-epitópok diverzifikációjával jár (3. ábra). Az anti-TG3-antitest dermatitis herpetiformis esetén magasabb a titerben, és gyakrabban pozitív (70-90\%), mint coeliakiában, amelynél a kezeletlen betegek 11-50\%-ában van jelen [16]. 


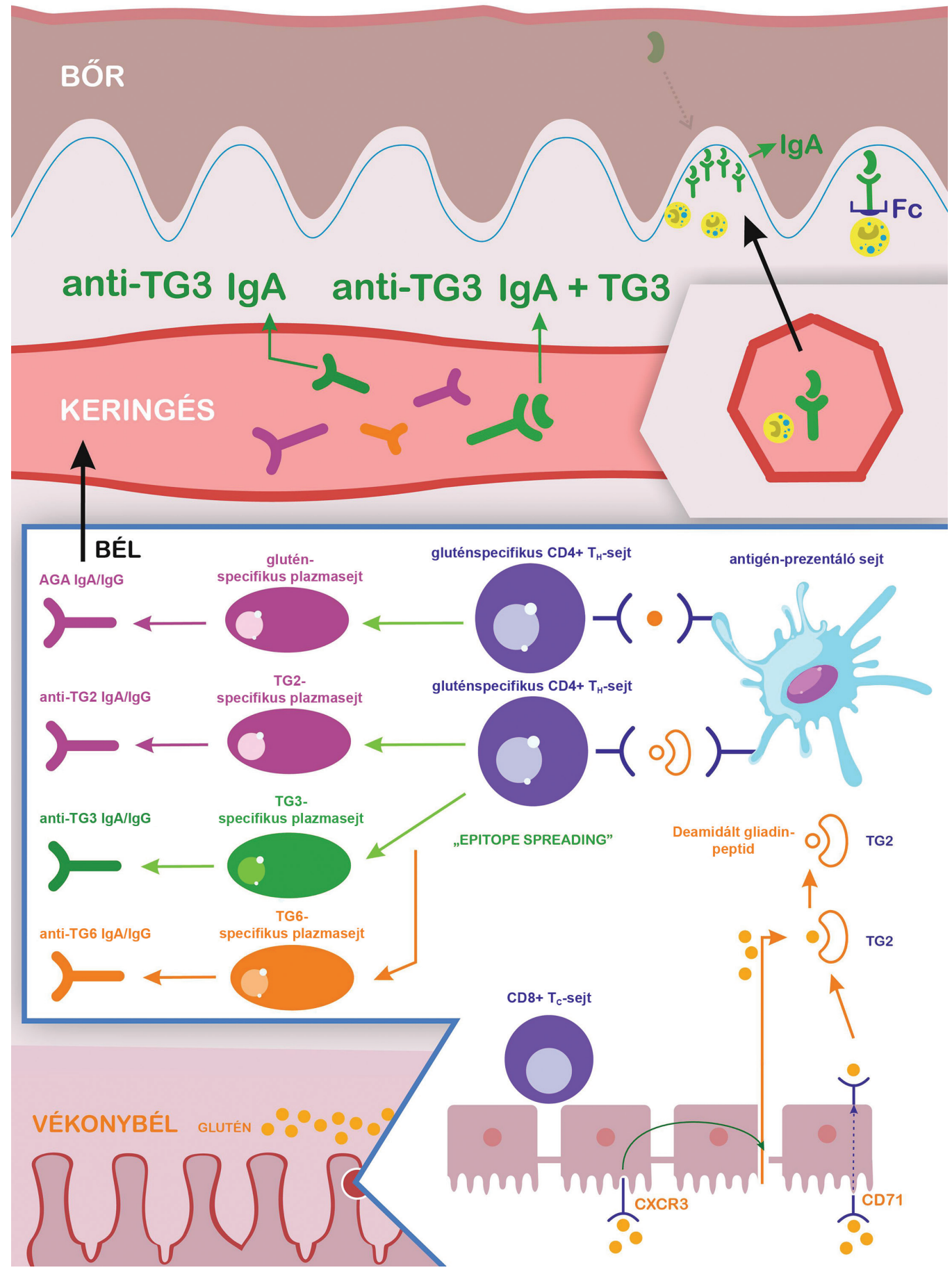

3. ábra

Bớr: a papillaris dermisben granuláris eloszlást mutató IgA-depozitumok kimutatása pathognomicus dermatitis herpetiformisban. Az IgA TG3-mal van immunkomplexben. A TG3 az epidermisből vagy a keringésból jut a papillaris dermisbe. Jellemző a szövettani képre a subepidermalis résképződés, valamint a papillaris dermis neutrophil granulocytás beszứródése. A granulocyták Fc-receptorukon keresztül itt kötődnek az IgA-depozitumokhoz. Keringés: a keringésből kimutathatók a gluténszenzitivitás intestinalis és extraintestinalis manifesztációira jellemző antitestek (anti-TG2 IgA/IgG, anti-TG3-IgA, anti-TG6 IgA/IgG), valamint a dermatitis herpetiformisban pathognomicus TG3-IgA-immunkomplexek.

Bél: az elfogyasztott glutén a vékonybél-nyálkahártya apicalis felszínén valószínúleg a CXCR3-receptorokhoz kötődik, ennek hatására a zonulinfelszabadulás átmeneti hámpermeabilitást okozhat, a 'tight junction' sejt közti kapcsolatok fellazulásával A lamina propria felé történó transzcelluláris gluténtranszportban a CD71-transzferrinreceptor is részt vesz. A TG2 által deamidált gliadin-peptid az arra hajlamosító HLA-allélt hordozó egyénekben indukálja az immunválaszt. A bélben zajlik a gluténindukált autoimmun betegségekben az autoantitest-termelés. Valószínú, hogy itt játszódik le az „epitope spreading” jelenség, ami a TG-enzimek epitópjainak diverzifikációjával járó dinamikus folyamat. A folyamat kezdetén csak a coeliakiára jellemző TG2-ellenes immunválasz figyelhető meg. A transzglutamináz enzimek, így például a TG2- és a TG3-molekula között nagyfokú homológia figyelhetó meg, így vannak közös epitópjaik. Coeliakiában az ezen közös epitópok ellen termelt antitestek keresztreakciója figyelhető meg. Ennek következményeként létrejöhet az „epitope spreading”, végül a TG3 saját epitópjaira specifikus, a TG2-vel már nem keresztreagáló antitestek jelenhetnek meg. Ennek során a lamina propriában gluténspecifikus CD4+ T-sejtek irányítják a TG3-specifikus B-sejtes választ. A coeliakia szövettani képére jellemző a CD8+ citotoxikus T-sejtek intraepithelialis infiltrációja

$\mathrm{CD}$ = differenciációs klaszter; Ig = immunglobulin; HLA = humán leukocytaantigén; TG = transzglutamináz 
A dermatitis herpetiformisban a dermisben megjelenő TG3 eredete máig nem tisztázott. Fiziológiás esetben a dermalis papillában nincs jelen az enzim, mely elsősorban a folliculusokban és a stratum spinosum magasan differenciált rétegeiben mutatható ki. Szerepe elsősorban az intakt cutan barrier biztosításában [36], az elszarusodás folyamatában és a hajszál struktúrájának kialakításában jelentős. TG2-t az epidermisben nagyobb mennyiségben a bazális keratinocyták expresszálnak [16]. A keringésben kimutatható anti-TG3-ellenanyagok nem kötődnek a papillaris dermishez, így a keringésben kimutatott TG3-IgA-immunkomplexek kicsapódása a bőrtünetek kialakulásának oki tényezője lehet, amire számos klinikai és ultrastrukturális sajátosság is utal (például acralis purpurák, a „DH body” struktúrájában immunkomplex-depozitumok a bőrben, valamint a vese- és a bőrerek falában) [26].

A pruritogenesis hátterében több gyulladásos citokin szerepét feltételezik, közülük az IL31-ellenes, célzott terápiától várnak eredményeket [37].

\section{Diagnózis}

A dermatitis herpetiformis diagnózisa négy fó pilléren nyugszik, ezek: klinikai kép, hisztopatológia, DIF és szerológia (anti-TG2-, illetve -TG3-ELISA vagy indirekt immunfluoreszcencia).

A bélbetegség verifikálására végzett bélszövettani vizsgálatok a coeliakiára jellemző gyulladásos szövettani képet mutatnak $[12,35]$. Immunfluoreszcenciás vizsgálattal a coeliakiára jellemző IgA-lerakódás látható a duodenojejunalis bazális membrán alatt és a lamina propria kiserei körül a mucosában, már gyermekeknél is. A TG2höz kötődő IgA a proximalis jejunumban, valamint a vékonybél egyéb szakaszain is kimutatható [13].

\section{Hisztopatológia}

A szövettani képre jellemző a subepidermalis résképződés, valamint a papillaris dermis neutrophil granulocytás beszűrődése. A hisztológia informatív lehet, de nem diagnosztikus értékú, gyakori a nem specifikus kép [6].

A résképződésben részt vesznek a neutrophil granulocyták. A belőlük felszabaduló proteázok hasítják a bazális membrán kapcsoló struktúráit. A granulocyták Fc-receptorukon keresztül itt kötődnek az IgA-depozitumokhoz [37].

\section{Direkt immunfluoreszcenciás börhisztológia (DIF)}

A dermatitis herpetiformis diagnózis felállításának sarokköve a DIF-vizsgálat. A mintavétel perilaesionalis, tünetmentes bőrterületről történik, általában 'punch' biopsziával. Az immunfluoreszcenciás képen a dermalis papillák csúcsán és/vagy a bazális membrán mentén granuláris
IgA-depozitumok láthatók. Ezek TG3 és anti-TG3-IgA által alkotott immunkomplexek, melyek a dermis kiserei mentén is kimutathatók. A folyamatot C3-festődés kíséri, aktív tünetekben fibrinogéncsapadékkal. A papillaris kiserekben esetenként IgG-, IgM-, C3-, Clq- és fibrinogénfestődés is megfigyelhető $[6,17,38]$. Nemritkán coeliakiás páciensek egészséges, illetve nem dermatitis herpetiformis bőrtüneteiben is kimutatható IgA-csapadék $[39,40]$.

\section{Szerológia}

A szerológiai vizsgálómódszerek hatékony szűrővizsgálatok coeliakia vagy dermatitis herpetiformis gyanúja esetén, ám szenzitivitásuk dermatitis herpetiformisban (a coeliakiával látható 95\% feletti értékkel ellentétben) csak 70\% körüli. A DIF-vizsgálat elvégzése minden esetben szükséges a diagnózis megerősítéséhez, hiszen egyébként coeliakiához társuló nem dermatitis herpetiformis eredetû bőrtünetet rosszul diagnosztizálhatnánk. A dermatitis herpetiformishoz társuló lappangó coeliakiaformák felismerésében és a diétás compliance megítélésében is központi szerepet játszik az anti-TG2-IgAellenanyag titerének meghatározása.

A coeliakia és dermatitis herpetiformis gyanúja esetén elvégzendő szerológiai vizsgálatok nem különböznek a mindennapi klinikai gyakorlatban. A két betegség szerológiai elkülönítését lehetővé tévő anti-TG3-IgA-ELISA rutinszerű használata sem hazánkban, sem más országokban nem terjedt még el.

Dermatitis herpetiformisban a keringő anti-TG3-IgAellenanyag szabadon vagy immunkomplex formájában is jelen lehet. A szabad és immunkomplexben kötött keringő antitestek mért koncentrációértéke között nem mutatható ki szükségszerüen összefüggés. Néhány páciensnél szeronegativitás vagy akár a bőr tünetmentessége esetén is jelen lehet a TG3-IgA-immunkomplex a keringésben, szintje a szabad ellenanyag titerétől független [26].

\section{Terápia}

A kórkép egyetlen, mai tudásunk szerint bizonyítottan hatékony gyógymódja az élethosszig tartó GMD, mely végleges remissziót eredményez. Betartása komoly erőfeszítést igényel; tapasztalatunk szerint hazánkban gyakoriak a diétahibák, a nem vagy elégtelenül diétázó páciensek. Finnországban a dermatitis herpetiformisos betegek 72\%-a tartott szigorú GMD-t (98\%-os adherencia) $[4,30]$.

Egy kisebb betegcsoporton vizsgálták, hogy dermatitis herpetiformisban szigorú GMD hatására a keringó TG3-, TG2-, EMA- és DGP-ellenes antitestek parallel kezdenek csökkenni [41], és 6-12 hónap alatt túnnek el a keringésből [4]. A GMD csak hetekkel, hónapokkal a megkezdése után tesz tünetmentessé, és csak akkor, ha megfelelően alkalmazták. A rejtett lisztbevitelről sokszor 
nem is tud a beteg, ugyanakkor nem szívesen tartják a körülményes és drága diétát; a betegek egy részénél tüneti dapszonkezelés is zajlik. Hazánkban a dermatitis herpetiformisos betegek jelentős része marad így tüneti terápiaként a gyógyszeren, ami csak a rendkívül kellemetlen tüneteket csillapítja. Így a páciens tévesen azt gondolhatja, hogy „meggyógyult”. A gyógyszeres kezelést igénylő páciensek aránya akár 65\% is lehet, a dapszon azonban súlyos, dózisfüggő hematológiai (methaemoglobinaemia, haemolyticus anaemia, agranulocytosis) szövődményeket okozhat. A máj nekroenzimértékeinek emelkedése jelentkezhet, továbbá ritka, rendkívül súlyos, magas mortalitású mellékhatás a dapszonszindróma vagy a hiperszenzitív reakció $[18,42]$.

Nem igazolt, hogy tartós GMD hatására a kórképben helyreállhat a gluténtolerancia. Egy finn vizsgálat kimutatta, hogy tartósan (átlagosan 23 éve) diétázó, szerológiával, bőr- és bélbiopsziával igazoltan remisszióban lévő 19 dermatitis herpetiformisos páciens közül 15-nél (79\%) jelentek meg a bőrtünetek átlagosan fél év után, akik közül 13 páciens bőre vált IgA- és TG3-pozitívvá. 13 páciens közül 12-nél a szerológia mellett bélbiopszia is igazolta az enteropátia újbóli megjelenését [42].

\section{A dermatitis herpetiformishoz társuló betegségek}

A társuló immunológiai és autoimmun megbetegedések közül gyakoriságuk miatt kiemelendő az l-es típusú diabetes mellitus, a Hashimoto-thyreoiditis és a vitiligo (2. táblázat) $[6,20]$. Új megfigyelés, hogy bullosus pemphigoid betegcsoportban végzett vizsgálat alapján a dermatitis herpetiformis előfordulása 22-szeres, a coeliakiáé 2-szeres a bullosus pemphigoidos betegek között. Azon dermatitis herpetiformisos páciensek közül, akiknél bullosus pemphigoid jelentkezett, 43,9\% szedett dapszont az azt megelőző két évben. A dermatitis herpetiformis és a bullosus pemphigoid diagnózisa között eltelt idó átlagosan 3 év volt [43].

Az enteropátia miatt kialakuló malabszorpciónak szerepe lehet bizonyos hiányállapotok létrejöttében (1. táblázat) [21]. A B $\mathrm{B}_{12}$-vitamin-, folát- és vashiány macrovagy microcytás anaemiát okozhat, a cinkhiány miatt pedig alopecia és fogszuvasodás alakulhat ki. A mineralizáció elégtelensége miatt megfigyelhetők a kórképre jellemző fogzománceltérések [23]. Mind a coeliakia, mind a dermatitis herpetiformis tünetei között gyakori a csontok ásványianyag-denzitásának csökkenése, ami mindkét betegség esetén az átlagpopulációnál nagyobb arányban hajlamosít csonttörésekre $[44,45]$.

A hosszú ideig kezeletlen dermatitis herpetiformis és coeliakia hajlamosít lymphoma, elsősorban nonHodgkin-lymphoma kialakulására. Dermatitis herpetiformisban jellemzően a B-sejtes, míg coeliakiában a vékonybélben a T-sejtes lymphoma kialakulásának rizikóját találták emelkedettnek [46].

Említésre méltó a gyakori jódérzékenység, amelyre a napjainkban széles körben elterjedt, kontrasztanyaggal végzett beavatkozások miatt is gondolni kell [23]. Régebben diagnosztikus tesztként is használták a kálium-jodid-tesztet, mivel a tünetmentes bőrön lokálisan alkalmazva indukálja a dermatitis herpetiformisra jellemző vesiculák megjelenését, továbbá a spontán tünetekhez hasonló perivascularis leukocytabeszưrődést idéz elő. A jód feltételezhetően a dermatitis herpetiformisos bőrben jelen lévő, IgA-hoz kötött TG3-enzimben okoz reverzibilis konformációváltozást és aktivitásnövekedést [47]. Ez lehet az oka, hogy a magas jódtartalmú ételek és táplálékkiegészítők rontják, nehezen kontrollálhatóvá teszik a betegséget, azok elhagyása pedig a tünetek javulásához vezethet [48].

\section{Gluténszenzitív neurológiai tünetek a bőrgyógyász szemével}

Egyre gyakrabban találkozunk gluténérzékenységhez társuló ritka, keringő TG6-autoellenanyagokkal jellemezhető neurológiai megbetegedésekkel. Ezek kialakulhatnak coeliakia mellett, igazolható TG2-autoimmunitáshoz kapcsolódóan, de annak hiányában is, csak AGA-ellenanyag-pozitív betegeken is [10]. A jelen cikkben elsősorban a TG6-ellenanyag-pozitív, coeliakiás és nem coeliakiás eredetú, gluténindukált neurológiai tüneteket tárgyaljuk mint autoimmun folyamatot.

\section{Genetika}

Az AGA-pozitív, neurológiai tüneteket mutató, kezeletlen coeliakiás betegek, akikben az enteropátia és a keringő TG2-IgA-ellenanyag is kimutatható, hordozzák a HLA-DQ2 (90\%) és HLA-DQ8 (5\%) allélokat, továbbá mintegy kétharmaduk TG6-ellenanyag-pozitív. Ezzel szemben vannak gastrointestinalis tüneteket nem mutató, nem coeliakiás, AGA-ellenanyag-pozitív, TG2-negatív és TG6-ellenanyag-pozitív autoimmun betegek is, akikben a coeliakiára jellemző allélok aránya a HLADQ8 javára tolódik el, illetve megnő a HLA-DQ1 gyakorisága.

\section{Epidemiológia}

Az újonnan diagnosztizált, felnőtt coeliakiás betegekben sokkal gyakoribb (67\%) a neurológiai tünet, mint a gyermekekben (6-10\%). A gyermekek 11\%-ánál írtak le további szubklinikus neurológiai elváltozásokat. A neurológiai tüneteket mutató gyerekek 25\%-ánál mutattak ki TG6-ellenes antitesteket egy másik vizsgálat során [49].

A vizsgált betegek $40 \%$-ában voltak kimutathatók antiTG6-antitestek. A pozitív szerológiával rendelkező betegek körében szignifikánsan nagyobb volt a subcorticalis atrophia előfordulása, mint a szeronegatív páciensek esetében [49].

A tünetek átlagosan 50 év feletti életkorban kezdődnek (coeliakia: 53 év; NCGS: 57 év). 


\section{Klinikai tünetek}

A gluténérzékenység által okozott neurológiai tünetek rendkívül színes képet mutatnak. A leggyakrabban előforduló két entitás a gluténataxia és a gluténneuropátia [49]. Ezenkívül előfordulhat még encephalopathia és kognitív zavar, illetve leírtak még myoclonust, myopathiát, myelopathiát, „stiff person” (merev ember) szindrómát, neuromyotoniát és choreát lényegesen kisebb gyakorisággal.

Gyakori a vékonyrost-neuropátia is. A gluténneuropátiás páciensek több mint fele számol be a bőrön fellépó fájdalomról, paradox égő érzésről, a simogatás, tapintás érzékelésének kieséséről, amit az A $\delta$ - és C-típusú rostok károsodása okoz. A gluténszenzitivitás miatt kialakuló AGA-pozitív vékonyrost-neuropátiák ritkán jelentkezhetnek axonhossz-independens formában is. A gluténérzékeny vékonyrost-neuropátiás betegek 46,2\%-ánál volt megfigyelhető ataxia is. A gluténérzékenységet megelőzően a betegek sokszor hosszú évekig járnak orvoshoz neuropátiás panaszokkal, mert a kórkép még nem közismert [50].

\section{Diagnosztika}

Gluténdependens neurológiai tünetek gyanújakor szükség van a gluténérzékenység igazolására AGA mellett az anti-DGP-ellenanyagok és a TG-autoimmunitás (keringő TG2- és TG6-ellenanyagok) vizsgálatával is. A lappangó coeliakiát komplex EMA-, TG2-, össz-IgAszérumszint-, bélbiopszia- és esetleg HLA-vizsgálattal igazolhatjuk minden kétséget kizáróan. Fontos kiemelni, hogy valamely TG-ellenes antitest nem mindig található meg a betegek szérumában, viszont gliadin elleni IgA és/vagy IgG különböző gluténérzékenységek esetében megfigyelhető. A gliadinellenes antitestek azonban a normálimmunválaszt jelzik, így ezek az autoimmun diagnosztikában nem használhatók, mert a betegségre se nem szenzitívek, se nem specifikusak.

\section{Kezelés}

A bél- és bőrtünetekhez hasonlóan a neurológiai tünetek fennállásakor is az élethosszig tartó, szigorú GMD jelent oki terápiát. A betegség progressziója lelassulhat, megállhat, sok esetben a tünetek javulhatnak is. A fejfájások gyakorisága és intenzitása is csökkenhet, akár meg is szűnhet. A regeneráció mértéke azonban függ a betegség fennállásának idejétől is.

\section{Gluténszenzitív hepatopathia a bőrgyógyász szemével}

A kórkép a kezeletlen coeliakiában előforduló májfunkciós laborparaméter-eltérések egyik oka lehet, melyre számos bőrtünet is felhívhatja a figyelmet. A transzamináz enzimek mérsékelt emelkedése (3-5-szörös) jellemzi. Ha a coeliakia okán károsodik a máj (coeliakiás hepatitis), a folyamat gluténdependens, és GMD-val jól kezelhető. A kezeletlen coeliakiás hepatitist periportalis gyulladás, a parenchyma mononukleáris gyulladása, steatosis, az epeutak elzáródása, a fibrosis minden stádiuma és cirrhosis is kísérheti. A fokozott intestinalis permeabilitás okán több toxin és egyéb, májat károsító ágens juthat a portalis keringésbe.

\section{Multidiszciplináris kollaboráció a gluténszenzitív betegségek kezelésében}

Bőrgyógyászati szempontból fontos tudni, hogy a gabonatartalmú ételek fogyasztása a dermatitis herpetiformis bőrtünetei mellett egyéb immunbetegségekkel (2. táblázat) $[6,20]$ és felszívódási zavarokkal (1. táblázat) [21], valamint autoimmun jellegú komplex idegrendszeri eltérésekkel társulhat. A gasztroenterológiai konzultációk mellett ezért a pácienseknél kialakuló idegrendszeri panaszok esetén a neurológiai vizsgálatok, de endokrinológiai-diabetológiai és fogászati ellenőrzés is szükséges. Fontos differenciáldiagnosztikai probléma lehet például a dermatitis herpetiformis tüneti kezelésére alkalmazott dapszonmellékhatás (perifériás neuropátia, anaemia), a kórképhez társuló l-es típusú diabetes mellitus és az osteoporosis okozta discopathiák (perifériás neuropátia), valamint a szekunder TG6-autoimmunitás okozta perifériás neuropátia elkülönítése.

A gluténérzékenység minden formájában kiemelten fontos a GMD szigorú betartása. A bőrtünetek enyhítésére nem szükséges tüneti kezelésként dapszont alkalmazni, mivel a szigorú GMD eredményeként a beteg egészségesebb lesz, és gyógyszerek nélkül is tünetmentessé válik. A diéta hatására a felszívódási zavarok rendeződnek, ami szintén életminőség-javulást eredményezhet, ám a társuló immunológiai és neurológiai eltérések egy részét nem tudja megszüntetni.

A bőrgyógyásznak a gluténszenzitív betegek felismerében és bőrtüneteik kezelésében, gondozásában jelentős szerepe van. Kiemelten fontos a kórképek interdiszciplináris szemléletű ellátása és követése.

Anyagi támogatás: A közlemény megírása anyagi támogatásban nem részesült.

Szerzői munkamegosztás: M. T.: Irodalomkutatás, a kézirat elkészítése. K. K.: A dolgozat átnézése, kiegészítése. G. A.: A dolgozat átnézése. A. A.: A dolgozat átnézése, véleményezése, javaslatok tétele. K. S., S. M.: A kézirat átnézése, véleményezése, kiegészítése, javítása. A cikk végleges változatát valamennyi szerző elolvasta és jóváhagyta.

Érdekeltségek: A szerzőknek nincsenek a dolgozat szempontjából releváns érdekeltségeik. 


\section{Irodalom}

[1] West J, Fleming KM, Tata LJ, et al. Incidence and prevalence of celiac disease and dermatitis herpetiformis in the UK over two decades: population-based study. Am J Gastroenterol. 2014; 109: 757-768.

[2] Sárdy M, Kornseé Z, Kelemen D, et al. Celiac disease screening among healthy blood donors in Hungary. Z Gastroenterol. 2013; 51: 1235-1239.

[3] Salmi TT, Kurppa K, Hervonen K, et al. Serum transglutaminase 3 antibodies correlate with age at celiac disease diagnosis. Dig Liver Dis. 2016; 48: 632-637.

[4] Hadjivassiliou M, Sanders DS, Grünewald RA, et al. Gluten sensitivity: from gut to brain. Lancet Neurol. 2010; 9: 318-330.

[5] Barbaro MR, Cremon C, Morselli-Labate AM, et al. Serum zonulin and its diagnostic performance in non-coeliac gluten sensitivity. Gut 2020; 69: 1966-1974.

[6] Caproni M, Antiga E, Melani L, et al. Guidelines for the diagnosis and treatment of dermatitis herpetiformis. J Eur Acad Dermatol Venereol. 2009; 23: 633-638.

[7] Kárpáti S, Sárdy M, Németh K, et al. Transglutaminases in autoimmune and inherited skin diseases: the phenomena of epitope spreading and functional compensation. Exp Dermatol. 2018; 27: 807-814.

[8] Dezsőfi A, Szebeni B, Hermann CS, et al. Frequencies of genetic polymorphisms of TLR4 and CDI4 and of HLA-DQ genotypes in children with celiac disease, type 1 diabetes mellitus, or both. J Pediatr Gastroenterol Nutr. 2008; 47: 283-287.

[9] Kárpáti S. Dermatitis herpetiformis: close to unravelling a disease. J Dermatol Sci. 2004; 34: 83-90.

[10] Kósnai I, Kárpáti S, Török É, et al. Dermatitis herpetiformis in monozygous twins: discordance for dermatitis herpetiformis and concordance for gluten-sensitive enteropathy. Eur J Pediatr. 1985; 144: 404-405.

[11] Al-Toma A, Volta U, Auricchio R, et al. European Society for the Study of Coeliac Disease (ESsCD) guideline for coeliac disease and other gluten-related disorders. United Eur Gastroenterol J. 2019; 7: 583-613.

[12] Mansikka E, Hervonen K, Salmi TT, et al. The decreasing prevalence of severe villous atrophy in dermatitis herpetiformis: a 45year experience in 393 patients. J Clin Gastroenterol. 2017; 51: 235-239.

[13] Kárpáti S, Kósnai I, Török É, et al. Immunoglobulin A deposition in jejunal mucosa of children with dermatitis herpetiformis. J Invest Dermatol. 1988; 91: 336-339.

[14] Kárpáti S, Stolz W, Meurer M, et al. Extracellular binding sites of IgA anti-jejunal antibodies on normal small bowel detected by indirect immunoelectronmicroscopy. J Invest Dermatol. 1991; 96: $228-233$

[15] Kárpáti S, Bürgin-Wolff A, Krieg T, et al. Binding to human jejunum of serum IgA antibody from children with coeliac disease. Lancet 1990; 336: 1335-1338.

[16] Sárdy M, Kárpáti S, Merkl B, et al. Epidermal transglutaminase (TGase 3 ) is the autoantigen of dermatitis herpetiformis. J Exp Med. 2002; 195: 747-757.

[17] Preisz K, Sárdy M, Horváth A, et al. Immunoglobulin, complement and epidermal transglutaminase deposition in the cutaneous vessels in dermatitis herpetiformis. J Eur Acad Dermatology Venereol. 2005; 19: 74-79.

[18] Reunala T, Salmi TT, Hervonen K. Dermatitis herpetiformis: pathognomonic transglutaminase IgA deposits in the skin and excellent prognosis on a gluten-free diet. Acta Derm Venereol. 2015; 95: 917-922.

[19] Pasternack C, Kaukinen K, Kurppa K, et al. Quality of life and gastrointestinal symptoms in long-term treated dermatitis herpetiformis patients: a cross-sectional study in Finland. Am J Clin Dermatol. 2015 ; 16: 545-552.
[20] Kárpáti S, Kósnai I, Verkasalo M, et al. HLA antigens, jejunal morphology and associated diseases in children with dermatitis herpetiformis. Acta Paediatr Scand. 1986; 75: 297-301.

[21] Kárpáti S, Gyulai R, Kemény L, et al. (eds.) Dermatology and venerology. 2nd edn. [Bőrgyógyászat és venerológia. 2. kiadás.] Medicina Könyvkiadó, Budapest, 2020. [Hungarian]

[22] Husby S, Koletzko S, Korponay-Szabó I, et al. European Society Paediatric Gastroenterology, Hepatology and Nutrition guidelines for diagnosing coeliac disease 2020. J Pediatr Gastroenterol Nutr. 2020; 70: 141-156.

[23] Kárpáti S. Dermatitis herpetiformis. Clin Dermatol. 2012; 30: 56-59.

[24] Salmi TT. Dermatitis herpetiformis. Clin Exp Dermatol. 2019; 44: 728-731.

[25] Juratli HA, Görög A, Sárdy M. Dermatitis herpetiformis. [Dermatitis herpetiformis.] Hautarzt 2019; 70: 260-264. [German]

[26] Görög A, Németh K, Kolev K, et al. Circulating transglutaminase 3 -immunoglobulin A immune complexes in dermatitis herpetiformis. J Invest Dermatol. 2016; 136: 1729-1731.

[27] Pasternack C, Kaukinen K, Kurppa K, et al. Gastrointestinal symptoms increase the burden of illness in dermatitis herpetiformis: a prospective study. Acta Derm Venereol. 2017; 97: 5862 .

[28] Hietikko M, Hervonen K, Salmi T, et al. Disappearance of epidermal transglutaminase and IgA deposits from the papillary dermis of patients with dermatitis herpetiformis after a long-term gluten-free diet. Br J Dermatol. 2018; 178: E198-E201.

[29] Salmi TT, Hervonen K, Kautiainen H, et al. Prevalence and incidence of dermatitis herpetiformis: a 40-year prospective study from Finland. Br J Dermatol. 2011; 165: 354-359.

[30] Hervonen K, Alakoski A, Salmi TT, et al. Reduced mortality in dermatitis herpetiformis: a population-based study of $476 \mathrm{pa}-$ tients. Br J Dermatol. 2012; 167: 1331-1337.

[31] Kárpáti S, Török É, Kósnai I. IgA class antibody against human jejunum in sera of children with dermatitis herpetiformis. J Invest Dermatol. 1986; 87: 703-706.

[32] Bognár P, Görög A, Kárpáti S. High prevalence of cryofibrinogenaemia in dermatitis herpetiformis. J Eur Acad Dermatol Venereol. 2016; 30: 517-518.

[33] Taylor TB, Schmidt LA, Meyer LJ, et al. Transglutaminase 3 pre sent in the IgA aggregates in dermatitis herpetiformis skin is enzymatically active and binds soluble fibrinogen. J Invest Dermatol. 2015 ; 135: 623-625.

[34] Görög A, Németh K, Szabó L, et al. Decreased fibrinolytic potential and morphological changes of fibrin structure in dermatitis herpetiformis. J Dermatol Sci. 2016; 84: 17-23.

[35] Hietikko M, Hervonen K, Ilus T, et al. Ex vivo culture of duodenal biopsies from patients with dermatitis herpetiformis indicates that transglutaminase 3 antibody production occurs in the gut. Acta Derm Venereol. 2018; 98: 366-372.

[36] Bognár P, Németh I, Mayer B, et al. Reduced inflammatory threshold indicates skin barrier defect in transglutaminase 3 knockout mice. J Invest Dermatol. 2014; 134: 105-111.

[37] Antiga E, Maglie R, Quintarelli L, et al. Dermatitis herpetiformis: novel perspectives. Front Immunol. 2019; 10: 1290.

[38] Barnadas MA. Dermatitis herpetiformis: a review of direct immunofluorescence findings. Am J Dermatopathol. 2016; 38: 283-288.

[39] Cannistraci C, Lesnoni La Parola I, Cardinali G, et al. Co-localization of IgA and TG3 on healthy skin of coeliac patients. J Eur Acad Dermatol Venereol. 2007; 21: 509-514.

[40] Bonciolini V, Antiga E, Bianchi B, et al. Granular IgA deposits in the skin of patients with coeliac disease: is it always dermatitis herpetiformis? Acta Derm Venereol. 2018; 99: 78-83.

[41] Reunala T, Salmi TT, Hervonen K, et al. IgA antiepidermal transglutaminase antibodies in dermatitis herpetiformis: a significant but not complete response to a gluten-free diet treatment. Br J Dermatol. 2015; 172: 1139-1141. 
[42] Mansikka E, Hervonen K, Kaukinen K, et al. Gluten challenge induces skin and small bowel relapse in long-term gluten-free diet - treated dermatitis herpetiformis. J Invest Dermatol. 2019; 139: 2108-2114.

[43] Varpuluoma O, Jokelainen J, Försti AK, et al. Dermatitis herpetiformis and celiac disease increase the risk of bullous pemphigoid. J Invest Dermatol. 2019; 139: 600-604.

[44] Pasternack C, Mansikka E, Kaukinen K, et al. Self-reported fractures in dermatitis herpetiformis compared to coeliac disease. Nutrients 2018; 10: 351.

[45] Lőrinczy K, Juhász M, Csontos Á, et al. Does dermatitis herpetiformis result in bone loss as coeliac disease does? A cross sectional study. Rev Esp Enferm Dig. 2013; 105: 187-193.

[46] Collin P, Salmi TT, Hervonen K, et al. Dermatitis herpetiformis: a cutaneous manifestation of coeliac disease. Ann Med. 2017; 49: 23-31.

[47] Taylor TB, Zone JJ. Sensitivity of transglutaminase 3 in the $\operatorname{IgA}$ aggregates in dermatitis herpetiformis skin to potassium iodide. J Invest Dermatol. 2018; 138: 2066-2068.
[48] Jimenez A, Hull C, Zone J. Dermatitis herpetiformis resistant to dapsone due to dietary iodide ingestion. JAAD Case Rep. 2019; 5: 713-714.

[49] Hadjivassiliou M, Croall ID, Zis P, et al. Neurologic deficits in patients with newly diagnosed celiac disease are frequent and linked with autoimmunity to transglutaminase 6. Clin Gastroenterol Hepatol. 2019; 17: 2678-2686.E2.

[50] Zis P, Sarrigiannis PG, Rao DG, et al. Small fiber neuropathy in coeliac disease and gluten sensitivity. Postgrad Med. 2019; 131: 496-500.

(Malkovics Tamás dr., Budapest, Mária u. 41., 1085 e-mail: malkovics.tamas_akos@med.semmelweis-univ.hu)

\section{"Gravius malum omne est quod sub adspectu latet." (Mindig súlyosabb a baj, ha nem látható.)}

\section{Az Orvosi Hetilap 2021, 162, 928. oldalán (23. szám) megjelent OH-Kvízre két helyes megfejtés érkezett.}

A beküldők: Dr. Kónya Csaba (Budapest) és Dr. Somogyi Erzsébet (Budapest).

A nyerteseknek szívből gratulálunk.

Nyereményüket - egy, az Akadémiai Kiadó webáruházában kedvezményes vásárlásra jogosító kupont - e-mailen küldjük el.

A cikk a Creative Commons Attribution 4.0 International License (https://creativecommons.org/licenses/by/4.0/) feltételei szerint publikált Open Access közlemény, melynek szellemében a cikk bármilyen médiumban szabadon felhasználható, megosztható és újraközölhető, feltéve, hogy az eredeti szerző és a közlés helye, illetve a CC License linkje és az esetlegesen végrehajtott módosítások feltüntetésre kerülnek. (SID_1) 